\title{
Environmental and Socioeconomic Impact of Copper Slag-A Review
}

\author{
Tlotlo Solomon Gabasiane ${ }^{1,2, *}$, Gwiranai Danha ${ }^{1,2}\left(\mathbb{D}\right.$, Tirivaviri A. Mamvura ${ }^{1,2}$ (D) Tebogo Mashifana ${ }^{2}$ (D) \\ and Godfrey Dzinomwa ${ }^{3}$
}

1 Department of Chemicals, Materials and Metallurgical Engineering, Botswana International University of Science and Technology, Private Bag 6, Palapye 10071, Botswana; danhag@biust.ac.bw (G.D.); mamvurat@biust.ac.bw (T.A.M.)

2 Department of Chemical Engineering, School of Mining, Metallurgy and Chemical Engineering, University of Johannesburg, P.O. Box 17011, Doornfontein 2088, South Africa; tmashifana@uj.ac.za

3 Department of Mining \& Process Engineering, Namibia University of Science \& Technology, Windhoek 13388, Namibia; gdzinomwa@nust.na

* Correspondence: tlotlo.gabasiane@studentmail.biust.ac.bw; Tel.: +267-463-2046

check for updates

Citation: Gabasiane, T.S.; Danha, G.; Mamvura, T.A.; Mashifana, T.; Dzinomwa, G. Environmental and Socioeconomic Impact of Copper Slag-A Review. Crystals 2021, 11, 1504. https://doi.org/10.3390/ cryst11121504

Academic Editors: Jie Dang, Jichao Li, Xuewei Lv, Shuang Yuan,

Katarzyna Leszczyńska-Sejda and Shujun Zhang

Received: 1 September 2021

Accepted: 16 November 2021

Published: 3 December 2021

Publisher's Note: MDPI stays neutral with regard to jurisdictional claims in published maps and institutional affiliations.

Copyright: (c) 2021 by the authors. Licensee MDPI, Basel, Switzerland. This article is an open access article distributed under the terms and conditions of the Creative Commons Attribution (CC BY) license (https:// creativecommons.org/licenses/by/ $4.0 /)$
Abstract: Copper slag is generated when copper and nickel ores are recovered from their parent ores using a pyrometallurgical process, and these ores usually contain other elements which include iron, cobalt, silica, and alumina. Slag is a major problem in the metallurgical industries as it is dumped into heaps which have accumulated into millions of tons over the years. Moreover, they pose a danger to the environment as they occupy vacant land (space problems). Over the past few years, studies have been conducted to investigate the copper slag-producing outlets to learn their behavior, as well as properties of slag, to have the knowledge of how to better reuse and recycle copper slag. This review article provides the environmental and socioeconomic impacts of slag, as well as a characterization of copper slag, with the aim of reusing and recycling the slag to benefit the environment and economy. Recycling methods are considered an attractive technological pathway for reducing waste and greenhouse gas emissions, as well as promoting the concept of circular economy through the utilization of waste. These metal elements have value depending on their characteristics; hence, copper slag is considered as a secondary source of valuable metals. Some of the pyrometallurgical and hydrometallurgical processes to consider are physical separation, magnetic separation, flotation, leaching, and direct reduction roasting of iron (DRI). Some of the possible metals that can be recovered from the copper slag include $\mathrm{Cu}, \mathrm{Fe}, \mathrm{Ni}, \mathrm{Co}$, and $\mathrm{Ag}$ (precious metals).

Keywords: copper slag; mineralogy; heavy metal; pyrometallurgy; hydrometallurgy; socioeconomic impact

\section{Introduction}

Numerous slags are produced as a second stream which is not desired in various metallurgical processes, e.g., copper slag (CS) from smelting and processing of copper ore [1,2]. The main mineral ore source for copper is chalcopyrite $\left(\mathrm{CuFeS}_{2}\right)$, with the smelting process contributing approximately $80 \%$ of the global copper production from around 21 million metric tons of ores being processed in 2018. The technology is always being improved due to the global importance of copper as a product. The metallurgical industries around the world are trying to find cost-effective and environmentally friendly ways to produce copper. Hence, technologies such as microbially driven metal leaching processes are used. Copper slag is subsequently produced as a byproduct which is solid waste and harmful to the environment but has the potential to yield viable metals if processed efficiently [3,4]. Waste management is one of the biggest challenges in the mining and processing industries, especially waste material such as copper slag. It is estimated that 2.2-3 tons of copper slag is generated per ton of copper produced, and this waste is mostly 
disposed of near smelter sites [5,6]. There are a significant number of copper processing plants around the world, and this has resulted in the production of about 24.6 million tons per year of slag, which is regarded as waste [7-9]. The main questions related to this slag are as follows: What does the slag contain? Is the slag harmful to the environment? Does it affect the ecosystem? What is its socioeconomic impact? Most mineral processing sites dispose of slag around the smelter; however, with the development of regulations over the years, threshold limits have been put in place to regulate its disposal to avoid bringing harm to the environment. The mining sector has given much attention to this problem by focusing on research to determine how to process slag to mitigate this challenge.

Africa is known to be a continent rich in minerals, and Botswana is one nation specifically rich in base metals such as copper, nickel, and cobalt. This paper focuses on copper slag which is generated by pyrometallurgical concentration of copper ores to produce copper/nickel matte by Bamangwato Concession Limited (BCL) in Botswana. BCL is a copper ore-processing plant established in 1960 in Botswana, situated in a town called Selebi Phikwe; however, it went into liquidation in 2016. The focus of the company was to extract copper and nickel from chalcopyrite, chalcocite, and bornite copper ores. The mining operations followed the standard convectional route using pyrometallurgical processes to concentrate the valuables (in this case, copper) [10-13]. The processing stream produced valuable copper/nickel matte and waste (copper slag). The amount of slag accumulated from 1960 until the closure of the mine in 2016 was millions of tons, which served as the motivation for this study. Smelting of copper is a pyrometallurgical process that generates smelter slag (copper slag), which comprises metals related to copper, e.g., nickel, zinc, iron, and cobalt [14-17]. Over the years, many mining and mineral processing operations have accepted the responsibility of protecting the environment by following safe disposal regulations of the waste produced. Since the waste is of no use to the mine operations, it is disposed of on vacant land, and it has accumulated over the years into heaps/mountains of copper slag. This slag also contains heavy metals which have concentrated over time and can be harmful to the environment if not taken into consideration during disposal.

Slags have different characteristics depending on how they are cooled from the smelter. This determines their structure and the distribution of heavy metals, base metals, and other minerals in the phases of the slag (Table 1). The world has taken a stand in viewing the economic benefits of the exploration of minerals, as well as the environmental considerations being implemented in the processing of these minerals to safeguard the environment and establish a sustainable process, leading to the introduction of sustainable metallurgy $[15,18]$.

Table 1. Phase and chemical composition of copper slag.

\begin{tabular}{ccc}
\hline & Metallurgical Waste & \\
\hline Elements & Copper Slag/Smelter Slag & Reference \\
\hline $\mathrm{Fe}, \mathrm{Ni}$ & $15.2-38.05$ & {$[16-18]$} \\
\hline $\mathrm{Cu}$ & $0.82-1.02$ & {$[9,17,19]$} \\
\hline $\mathrm{Si}$ & 13.6 & {$[19]$} \\
\hline Silicates & Glass fayalite & {$[16]$} \\
\hline
\end{tabular}

Iron has played a major role in the industrialization and global development of the modern world, including Botswana. Iron is an important metal due to its properties which make it relevant to the construction sector. Botswana is a nation that relies on the importation of most of its building materials such as iron, and it depends on the mining sector to generate this revenue. Most of the mines in Botswana are involved in mining diamonds, gold, copper, and nickel but not iron, as there is no primary iron ore source. The metal is associated with other ores such as copper and nickel. Another approach could be to use copper slag as a source of iron. 
Botswana has been hit hard by the closure of copper and nickel mines, because this has resulted in thousands of people losing their jobs and the country being affected economically. A steel-making plant in Selebi Phikwe town was also closed due to the lack of scrap metal used as a feed material, mainly because of the scarce availability of scrap generated by the low population of Botswana, which is around 2.3 million. This article reviews the possibility of using slag accumulated from the closed mines for beneficiation and recovery of iron and copper from copper slags.

Previous research on slag supports this investigation, with researchers from the biggest mining sectors involving copper slag from as far as Chile and Turkey still investigating the reclamation of valuables from copper slag $[8,20]$. Botswana faces similar problems with high yields of slag produced over time, which have had a high impact on the environment [21]. The mining and the processing of ores for many years have led to high-grade ores being depleted; hence, a new approach using copper slag from BCL and Tati Nickel mines as a secondary source of raw materials can be considered [17]. There are several impacts associated with mining as shown in Figure 1; hence, it is more advantageous to process an already abundantly available slag as opposed to starting new mining activities. This brings into perspective the concept of diversification of the reclamation of valuable metals from slag.

This review article focuses on the negative impact of mining and processing minerals on the environment, and whether these effects are adequately regulated. A typical example is Asia, the continent with the largest production of copper slag in the world through producing 7.26 million tons of copper slag per annum [22,23]. Therefore, there is a need for utilization of this generated copper slag. North America, Europe, South America, Africa and Oceania produced 5.90, 5.56, 4.18, 1.23 and 0.45 million tons of copper slag per annum [24].

\subsection{Case Studies on Copper Slag}

Copper slag is perceived as a negative impact, and previous research has investigated its potential effect on different stakeholders. Many countries mine copper and nickel, which in turn generates millions of CS, and substantial funding has been invested to focus on finding sustainable ways of using CS to their benefit. Two case studies from different countries on the impact of and possible solutions for CS are presented below.

\subsubsection{Chile}

A good example is Chile, where copper smelters generate a large amount of CS, which causes similar problems to other copper-producing nations such as Botswana. The major problem is CS landfilling, which leads to environmental problems, but this can be tackled using modern pyrometallurgical processes. Consequently, the focus has been on minimizing and reusing the CS to benefit all stakeholders involved, subsequently leading to saving costs, environmental rehabilitation, and a source of economic benefit. Chile has conducted extensive tests on recovery and value addition using CS to address the abovementioned issues and processes, including highly intensive direct reduction to form different types of alloys such as $\mathrm{Fe}-\mathrm{Cu}-\mathrm{C}$, which can be used in metal industries such as steel production. Some of these alloys obtained reflect sponge iron properties, which can be pelletized before magnetic separation to get iron. This in turn could be a viable approach toward the recovery of metals [8]. Thus, it I s worthwhile for Chile to take the necessary research steps toward utilizing CS to their advantage and benefit.

Chile has copper oxide ores which are processed using hydrometallurgy and output using flotation (smelter) [25]. This process also involves leaching of low-grade copper ores (sulfide-based). The focal leaching methods used over the years have involved heaping, dumping, and running of mine leaching, with them being separated on the basis of particle size in the leaching pad [26]. The authors of [27] stressed the importance of physicochemical characterization when studying and grading slags with respect to the possibility of reclaiming viable metals. Various experiments have been undertaken in the recovery of 
iron or iron/molybdenum using direct reduction; with the iron content remaining constant, the copper content is reduced intensively, indicating selective reduction [27].
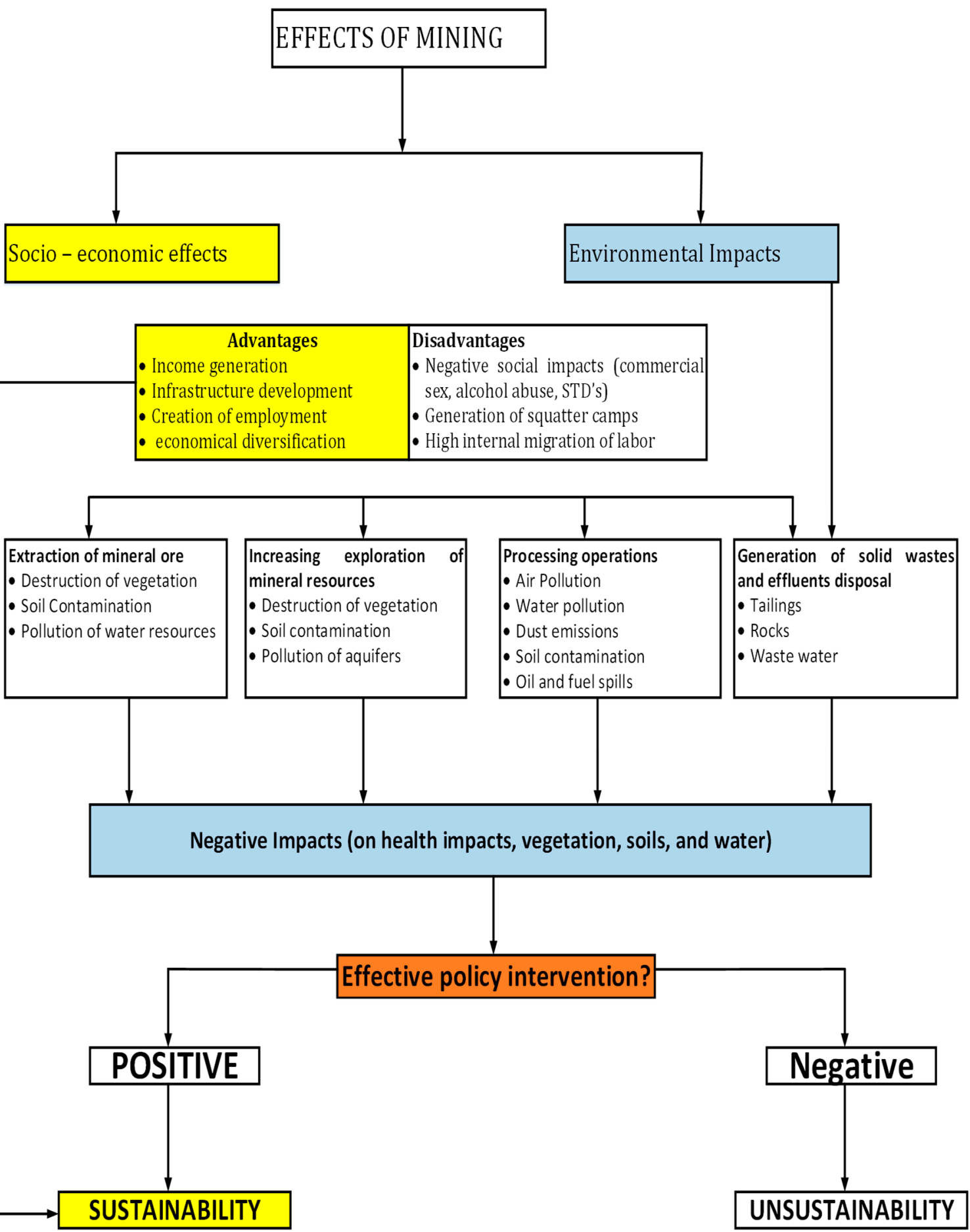

Figure 1. Conceptual diagram illustrating effects of mining [28].

Most of the phases in copper- and nickel-bearing ores are bornite, chalcopyrite, and chalcocite, which can be quantified using QEMSCAN. Copper slag following the production of copper and nickel includes phases such as $\mathrm{Cu}-\mathrm{Fe}-\mathrm{S}$ [19]. Table 1 shows the chemical composition of copper slag. The mechanical and physical properties of slags differ depending how the slag was cooled with most of slag having a unit weight ranging between $2800-3800 \mathrm{~kg} / \mathrm{m}^{3}$, Bulk density between $144 \times 162 \mathrm{Ib}$ per cubic feet, hardness 
of $7 \mathrm{Moh}$, appearance being black, glassy, vesicular when granulated, abrasion loss of 24.1 and a specific gravity of 2.8-3.8 [22].

\subsubsection{Zambia}

Zambia, located in southern Africa, is another good example, and it suffers from similar problems to Chile and Botswana brought about by CS. A sample of slag from a dump (landfill) located at Nkana, Zambia was characterized, and it was realized that it contains a substantial quantity of cobalt. The Nkana dump includes 840 tons of slag with $0.66 \%$ Co processed per 100 tons of cobalt-bearing alloy composed of $5-14 \%$ Co [29]. This metal is used in various commercial and military applications due to its properties. Co is an element that can be attained in the form of rods, blocks, or powder; it is stable above $417^{\circ} \mathrm{C}$ in its closed packed hexagonal form [30]. The monthly average report for the US in March 2021 indicated that the Co price increased by 7\% from February, being 43\% higher than March 2020. The London Metal Exchange (LME) also showed an increase in cash mean price by 11\% from February, being 74\% higher than March 2020 [30]. The prices for cobalt metal in March 2021 (USD per pound) were as follows: US, range of 23.00-26.25 at an average price of 24.75; LME, range of 22.96-23.95 at an average price of 23.80 [30]. This led stakeholders to build a $40 \mathrm{MW}$ arc furnace in Chambishi with the sole purpose of recovering cobalt from CS. This extraction of cobalt has proven to be a success, producing about 100 tons of cobalt-bearing alloy (with $5-14 \%$ Co) [29]. Cobalt is a very expensive metal due to its properties and rarity.

\subsection{Significance of This Review}

Even with the attention given to this subject in the past, there has not been a dedicated review concerning metallurgical waste in Botswana. This review conducts an initial investigation, followed by documenting the progression, achievements, and challenges in the utilization of smelter slag. It focuses on the reclamation of valuable metals from smelter slag, exploring the different processing and recovery phases relevant to the metallurgical waste reclamation of mineral elements with reference to the properties of smelter slag. It goes on critically evaluate the environmental and socioeconomic impact of slag on relevant stakeholders, especially in Botswana.

\subsection{Types of Metallurgical Slags}

Slag can be classified as ferrous or nonferrous slag, with CS being part of the latter group. The former group comprises iron and steel slags with geochemical application, e.g., in road and ballast railroad construction in Europe and United States in the early 19th century. They still have significant use in engineering fill materials [31]. Botswana contributes to the production of copper slag in Africa, most of which is dumped on vacant land, thus accumulating into mountains that occupy viable land.

\subsubsection{Ferrous (Fe) Slag}

The process of recovering iron from its parent ore or secondary recyclable material (to produce steel or iron) produces ferrous slag. Slags are produced under high temperatures which can only be achieved in a furnace. Slags differ depending on the conditions used in the furnace and how it is subsequently cooled. The core purpose of a blast furnace is to reduce iron oxides into molten iron via the addition of coke (flux). The slag in the molten state needs to be cooled, and the way it is cooled determines its properties and commercial use; for example, in the recovery of copper, slow cooling of slag leads to a recovery of about 98.5\% [32-34]. The molten slag solidifies during cooling in different ways depending on whether it is cooled under atmospheric conditions, by using measured quantities of water, by rapidly chilling in air (pelletized), or by quenching with high-pressure water to form granules. The authors of [33] illustrated different aspects brought about by the fast and slow cooling of slag. 


\subsubsection{Nonferrous Slag}

The focus of this review is on nonferrous slags, which are mainly generated from hightemperature processes such as smelting (pyrometallurgical). Nonferrous slag is formed as a byproduct of metal recovery from nonferrous ores. Some nonferrous ores include chromite $\left(\mathrm{FeCr}_{2} \mathrm{O}_{4}\right)$ and chalcopyrite $\left(\mathrm{CuS}_{2}\right)$ [35], are also associated with other base metals. The ores of interest are copper ores and mostly sulfide ores such as pyrite $\left(\mathrm{FeS}_{2}\right)$. All these ores may be linked to one another because they are associated with different metals, but copper and nickel are the primary metals of interest for recovery as they do not have pure ores which exist on their own [36]. These sulfide ores generate concentrates that contain targeted metals $(\mathrm{Cu}, \mathrm{Ni}, \mathrm{Zn}$, etc.) and subsequently produce slag as a byproduct, which is considered waste material. The authors of [37] investigated the production of nonferrous slag from parent ores. Several nonferrous ores are processed across the globe due to the high demand for target metals, giving rise to a high production of nonferrous slags. Some of the processing steps involved in treating these nonferrous ores (sulfide ores) involve concentrating, roasting, and smelting.

$\mathrm{Cu}$ and $\mathrm{Ni}$, mostly sulfide ores, are processed using pyrometallurgical techniques that yield slag as a byproduct. Not all base metals exist in parent ores; hence, they are not all extracted from sulfide ores. This is evident with $\mathrm{Cu}$, which can also be extracted from oxide and carbonate ores, whereby the optimal recovery technique is not pyrometallurgy. This paper mostly represents research on sulfide ores, such as chalcopyrite $\left(\mathrm{CuS}_{2}\right)$ from the BCL mine in Botswana, which is a parent ore of $\mathrm{Cu}$ and Ni. Such ores are associated with other metal elements, such as $\mathrm{Co}$ and Fe. This review focuses on CS which contains nontarget metal elements discarded from the concentrate, which is estimated to be between 45 and 55 million tons in Botswana [38]. Botswana also has similar copper/nickel-bearing ores which are sulfide in nature. BCL produced copper slag, which was disposed of near the mine since its inception (1960). The slag has since accumulated.

The relationship between the quantity of slag produced and the metal produced differs on the basis of the product. The authors of [39] estimated that approximately 0.6 tons of slag is produced for each ton of $\mathrm{Pb}$ by a smelter in France. According to [19], about 2.2 tons of slag is generated for each ton of $\mathrm{Cu}$ generated around the globe.

The pyrometallurgical processing of $\mathrm{Cu}$ involves the usage of water; hence, wastewater is also produced. Some mining operations recycle the water for further usage in the plant. This wastewater contains chemicals and minerals which also pose a potential threat to the environment when disposed of at dumpsites [40].

\section{Uses of Metallurgical Slag}

Multiple slags are generated as byproducts to processing minerals (metallurgical processes), and their characterization is an important aspect to determine the number of valuable metals they contain and what process routes can be taken to recover those metals. Across the globe, slag is generated at a rate of 2.2 tons per ton of copper generated, and this enormous rate gives rise to an annual figure of 24.6 million tons of slag. Characterization of the slag is important to determine its composition and the process route(s) for efficient recovery $[7,41,42]$.

Characterization of feed materials allows determining the expected grade concentration and metal recovery, which is vital for the design of extraction flowsheets for the sustainable development and utilization of secondary ore resources [17,43,44].

In previous studies, the initial characterization of smelter slag was followed by the proposal of a process route to utilize the slag. The slag can be characterized using Xray diffraction (XRD), Fourier-transform infrared spectroscopy (FTIR), scanning electron microscopy with energy-dispersive spectrometry (SEM-EDS), and light optical microscopy (LOM) in transmitted and reflected light [45-47]. Previous studies have indicated that copper slag behaves differently when subjected to different temperatures, thus exhibiting different properties [42,48]. BCL slag was characterized to analyze its composition. SEM images revealed $\mathrm{Fe}-\mathrm{Cu}-\mathrm{Ni}$ within the glass host due to the rapid cooling of slag. Fayalite, 
chromite, sulfide, and glass phases were also identified, with iron in the fayalite and glass phases at 12.85 and 85.19 abundance, respectively. XRF results indicated $35.4 \% \mathrm{Fe}$, $0.29 \% \mathrm{Cu}, 0.28 \% \mathrm{Ni}$, and $0.14 \% \mathrm{Co}[49]$.

The chemical composition of CS [27] revealed a high concentration of Fe as the main mineral constituent in all four phases. Phase 3 contained the least amount of Fe at $11.28 \%$, compared to the other phases having a concentration between $50 \%$ and $65 \% \mathrm{Fe}$ [21,50,51]. Thus, this significant amount of Fe can be taken into consideration for recovery. The authors of [52] discussed the importance of characterizing CS using X-ray, SEM, and EPMA. Chile is one of the largest miners of copper, with the slag revealed to contain $83-92 \%$ copper $[53,54]$.

Chile is at the forefront of copper slag generation, which has triggered vast research on metallurgical slag utilization. Their slag was observed to be black with a glassy appearance. It is mainly granulated and porous with lower specific gravity, comprising regular shaped angular particles between 0.075 and $4.75 \mathrm{~m}^{3}$ in size [55].

\subsection{Slag as a Secondary Resource Ore}

This paper investigates the sustainable reuse of metallurgical waste (copper slag) generated during the production of minerals. Waste management regulators across the world have encouraged such industries to find ways of reducing the generation of waste, as well as reusing and recycling this waste, due to environmental and socioeconomic concerns. This has led to a vast interest in metallurgical waste due to its magnitude produced by mineral-processing industries; accordingly, a previous study suggested that metallurgical waste can be treated as a secondary source of minerals or as a building material, meeting the standards of the regulatory authority of waste management [56,57]. Some of these metallurgical industries target certain minerals such as copper and nickel in copper/nickel smelting operations. Copper and nickel ores usually contain Fe and sulfide; hence, it is ideal to use smelting to recover copper and nickel. Copper and nickel were treated via flotation and smelting of the concentrate to yield 42,000 $\mathrm{mt}$ of nickel/copper matte per annum at the BCL mine [11]. Other minerals associated with copper ore are not of interest; therefore, during the recovery of target metasls, the undesired associated metals are lost in the slag and accumulate over time. Some of these metals include Co, REEs, and iron in the case of BCL smelter operations in Botswana. These metals are of great importance due to their properties $[25,51,55,58-60]$.

Several technologies have been improved over the years for the recovery of metals contained in CS, with one in particular being direct reduction-magnetic separation by adding $\mathrm{Na}_{2} \mathrm{CO}_{3}$ and $\mathrm{CaO}$ to upgrade copper slag from $40.33 \% \mathrm{Fe}_{\text {total }}$ and $0.65 \% \mathrm{Cu}$ to $94.3 \%$ and $86.5 \%$, respectively [61]. The authors of [55] gave a good account of different process routes used to recover metallic elements from slag using a three-way approach.

\section{Reuse and Recycling of Copper Slag}

This review aimed to evaluate the potential of copper slag. Slag is formed via pyrometallurgical processes; hence, hydrometallurgy plays an important role in the study of recycling slag to find viable metallic elements. Direct reduction is one method used to recover iron from the slag by reducing $\mathrm{Fe}_{3} \mathrm{O}_{3}$ and $\mathrm{Fe}_{2} \mathrm{SiO}_{4}$ found in copper slag to metallic iron using coal. This involves using reduction temperatures of about $1300{ }^{\circ} \mathrm{C}$ over the course of $30 \mathrm{~min}$, giving an output of $98.13 \% \mathrm{Fe}$ [48]. Iron is a vital metal element that encourages the growth of humanity and national economies [62,63]. As iron is mostly sourced from its parent ore, using copper slag as an alternative source will subsequently benefit the environment, as it will revamp and rejuvenate the environment where slag was dumped and stored. The newly open land could then be reintroduced into the ecosystem and used for more productive activities such as farming and other industrial ventures.

Copper slag, as its name suggests, contains traces of copper, and most copper ores are associated with other metallic elements such as cobalt. Various studies have been conducted to recover copper and cobalt using magnetic separation and sulfuric acid leaching of copper slag containing $\mathrm{Cu}-\mathrm{Co}-\mathrm{Fe}$. The sample was subjected to wet grinding to allow magnetic 
separation, producing $95.75 \%$ cobalt, while $87.8 \%$ of copper and $44.39 \%$ of iron remained in the tailings [12].

With the depletion of high-grade ores over the years due to the demand for minerals, different types of pyro and hydrometallurgical processes have been used to recover viable metals such $\mathrm{Fe}, \mathrm{Cu}, \mathrm{Co}$, RREs, and $\mathrm{Ni}$. Their characterization allows determining processing routes depending on the phases they are present in.

CS can also be feasibly processed by ammonia solution treatment to yield significant and viable yields of copper [64]. Using microwave treatment to treat CS slag to recover iron at high concentrations is another viable option [65]. For copper and nickel, leaching or flotation is typically used for recovery from CS [33]

Botswana used to produce copper from Bamangwato Concession Limited [66], Khoemacau, and Tati Nickel mines. These mines also produced slag, which was disposed into heaps. The slag from BCL was produced from the smelter unit where nickel and copper matte were produced. Approximately 833,393 tons of slag was produced in 1998 with no plan for land reclamation at the slag deposition sites at the time [28]. The slag at BCL was rapidly cooled using water sprayed at high intensity, giving it a glassy dark shiny look. The outer layer of the slag had a tough appearance when handled. The disposed slag usually contained iron, copper, zinc, cobalt, nickel, silver, and gold [66]. All these metals have different demands; for example, iron has a high demand locally in Botswana and internationally, especially in China. The iron content in CS is sometimes more than that in the parent ore due to the concentration of iron over years of disposal [67]. The iron content in copper slag generated by pyrometallurgical processes is approximately $35 \%$ to $45 \%$ according to [68]. The iron content found in BCL copper slag that can be recovered is $35.4 \%$ [69]. Botswana suffered the recent closure of Pula Steel due to a lack of the main raw material, i.e., scrap iron; however, due to the small pollution of Botswana, this was not sustainable in that manner. Therefore, utilization of copper slag for recovering iron can be used to feed the steel plant, stimulating its resurrection. This can also help in the waste management of slag, thus reducing environmental pollution. Most slags contain $40 \mathrm{wt} . \%$ iron, and extraction of this iron from CS is ideal [70].

\subsection{Slag for Construction}

Slag possesses different properties and characteristics, which make it suitable for making construction materials depending on the processes the slag was subjected to $[1,19]$. Thus, characterization allows establishing the suitability of the slag by looking at its mineralogy and behavior under set conditions. Thus, the slag can be utilized instead of it being stockpiled over usable and potentially fertile land for farming [71,72].

\section{$\mathrm{Cu}$ Slag in Concrete}

Copper slag comprises pozzolanic characteristics due to it containing low amounts of $\mathrm{CaO}$ and other various oxides such as $\mathrm{Al}_{2} \mathrm{O}_{3}, \mathrm{SiO}_{3}$, and $\mathrm{Fe}_{2} \mathrm{O}_{3}$. This aspect of replacing components of concrete with slag can reduce the slag being dumped on vacant land, which causes problems for the environment and involved stakeholders. This reduces the costs of dealing with the slag to meet environmental regulations, as well as reducing costs for the development of cement, as the slag is of low cost or even free. In many ways, this is an advantage for concrete manufacturers and metallurgical industries [73,74]. CS slag, depending on the technique used to cool it, bears properties that can be used in the construction industry as it can be used as an aggregate [75]. CS slag is becoming popular around the globe as an auxiliary of sand in concrete, mostly in Singapore [76].

Depending on the processing route, different properties such strength-to-weight ratio determine the effective use of slag in concrete $[1,77,78]$. The authors of [79] further highlighted the use of CS as a fractional auxiliary replacement of fine aggregates to evade the discharge of carbon dioxide from cement in concrete. As previously highlighted, slag can be cooled slowly or quickly, which determines its granulation output and, thus, its suitability as a sustainable building material, e.g., as a fine aggregate in cement $[75,80]$. 


\section{Environmental Impact of Slag}

It is vital to test CS for the leaching of heavy metals, especially when used in valueadded products such as construction materials. CS disposed of in heaps of vacant land tends to be left alone with the assumption that it is waste; however, it is exposed to environmental conditions such as rainfall. This can prompt leaching of metals associated with the slag. The leached heavy metals can pollute drinking water. These heavy metals may include lead, arsenic, cadmium, iron, copper, and cobalt [71], which can affect the soil, water, animals, and people. Thus, review aimed to gather enough evidence to articulate the impact of slag on the environment and other relevant stakeholders.

\section{Effect of Slag on People and Animals}

The mining industry produces a concentrate and a byproduct (mainly slag), which contains heavy metals associated with the ore processed. These metals can be toxic and harmful to the environment. The environment can be exposed to these heavy metals in different ways, both natural and anthropogenic. CS contains various heavy metals such as lead, arsenic, copper, nickel, iron, and cobalt. Even though these metals are at low concentrations, following prolonged disposal, their concentration can increase over time with effects on the environment (plants, animals, and human beings) [39,81,82]. One of the most common effects on humans caused by the ingestion of copper is paralysis, which in most cases leads to death due to gastric hemorrhage. Furthermore, skin exposure can cause acute dermatitis [83]. The authors of [84] illustrated the toxicity of heavy metals toward plants and soil, as well as possible avenues for their use to decrease the level of toxicity to the environment [85].

Previous studies have been conducted in the Selebi Phikwe mining town, Botswana, whereby residents were given questionnaires regarding the environmental and socioeconomic impact of the mine (Table 2).

Slag, as discussed above, can be categorized as ferrous or nonferrous, which both have negative impacts on the environment if the disposal standards are not observed [86]. 
Table 2. Summary of data collected and analyzed from BCL mine [28].

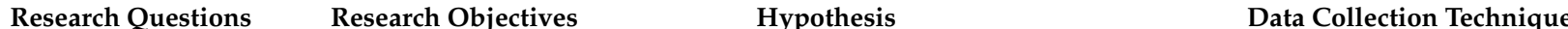

- Collected socioeconomic data from respondents using questionnaires mining activities had on local employment and incomes, investments, socioeconomic impacts of the mine on the local people
The copper/nickel mine in Selebi Phikwe is having a deleterious impact or and the environment relevant departments and agencies to obtain additional information on the socioeconomic and environmental effects of the mine in the area

- In addition to the socioeconomic data on health collected medical records from hospitals and clinics in Selebi Phikwe

- Collected employment statistics from BCL and Council for analysis

- Collected socioeconomic data for analysis

- Conducted documentary search to ascertain other

information

The copper/nickel mine in the copper/nickel mining operation on soil, water resources vegetation cover, and from mining and wastes affect the surrounding environment in Seleb air quality in and around Selebi Phikwe

Selebi Phikwe is having a deleterious impact on people and the environment discharges, and soil and vegetation samples from $B C L$ mine to assess the extent of the impact on the environment and people

- The perceptions of respondents and institutions were obtained through interviews of key informants

- Environmental policies of the government were examined in line with the company's current

Assess the compliance and effectiveness of the xisting environmen mitigation and

To what extent are the environmental policies of the government management measures implemented by the company
The copper/nickel mine in Selebi Phikwe is having a deleterious impact on people and the environment environmental policies; other documents were to supplement the data collected from the field

- Conducted interviews with the Environmental

- Departments of mines and other relevant institution

Carried out field observations to examine physical changes of environment in the study area

\section{Results Obtained from the Study}

- Socioeconomic data from respondents showed that BCL provides employment opportunities

- Socioeconomic data from council officials showed that BCL brought about financial aid to the community surrounding the $\mathrm{BCL}$ mine and to Botswana

- Medical records showed that animals which drank water dissolved from slag and mining operation became ill and died; an effect on the water table and, subsequently, drinking water (boreholes) was suspected

- Employment statistics showed that the was a downfall in Selebi Phikwe as mostbusiness relied on the mine in Selebi Phikwe as most busin

- Socioeconomic data showed that the mine environmental risk provided a risk to the ongoing socioeconomic benefits

- Documentary search showed that slag was disposed of efficiently while ignoring long-term environmental risks

- $\quad \mathrm{BCL}$ data on $\mathrm{SO}_{2}$ estimates showed that $8.8 \%$ of sulfur is captured and fixed in slag and matte, $9.5 \%$ escapes via converters, and $82 \%$ leaves via the flash furnace

- Interviews showed that emissions from the mine have effects on breathing and being asthma, as well as the livestock's drinking wate

- Environmental policies showed that the waste was generalized instead of specified to mine waste, making it difficult to cap and control emissions and disposals by mine waste, leading to most mines using internal regulatory policie

- Interviews showed that most of the polices were not

- Field observations showed that the soil covered by the slag and around the slag changed in terms of texture and color due to the heavy metals present in the slag, while ponds of water were also discolored 


\section{Socioeconomic Impacts}

Copper slag is perceived as waste material from the metallurgical processing of mineral ores and, hence, poses a risk to the environment. Therefore, reusing the slag for aspects of concrete and for reclamation of valuable metals from the slag will prove beneficial to the environment and, subsequently, the economy. This article reviews potential methods for the utilization of BCL smelter slag (copper slag). Instead of viewing copper slag as a waste product, it can be seen as having environmental and economic importance. Mines and plants have a responsibility toward the environment according to standards, making it less harmful after the recovery of heavy metals which can be of economic value. The less reactive or inert slag can be used for other purposes including construction as a replacement material in building materials such as cement [87].

In southern Africa, mining has been the backbone of many countries, most notably Botswana, where minerals such as copper and nickel are mined as a matte concentrate, yielding CS as the byproduct. In the early mining days of this industrial era, less research was conducted on the environmental implications brought about by the CS generated from the process. The mines were mostly focused on optimization and efficacy to produce better concentrates and, thus, more profit at the cost of the environment brought about by the handling and disposal of waste. Botswana was one of the top three mineral producers in Africa, along with the Democratic Republic of Congo and South Africa. The use of CS as a secondary source can provide over 10,000 jobs, which is critical for the sustainability of the mining industry [88].

\section{Socioeconomic Impact of Metallurgical Slag in Botswana}

CS has several harmful implications if not handled and disposed of correctly. As it has mainly been seen as waste over the years, less attention has been given to it in terms of research [89]. The authors of [90] highlighted the importance of keeping tabs on the concentration levels of heavy metals found in slag to avoid long-term environmental impacts. Another route to keep levels of heavy metals in line with environmental regulations is to utilize the CS sustainably.

Previous studies have illustrated that, over the years, high-grade ores have been used up, and waste such as CS is seen as a potentially rich secondary source of viable minerals. Characterization of CS is important to determine its behavior and mineral composition, thus allowing the identification of possible recovery routes for extraction. Iron ore is regarded as viable if contains at least $35 \% \mathrm{Fe}$, and CS such as that of $\mathrm{BCL}$ can meet this requirement. Iron is a very important element for economic growth. Copper is another important metal, and its current market price is the highest considering the last 10 years [22]. Copper and nickel are usually found in the sulfide phase, and previous research has indicated that the best possible recovery routes involve flotation and leaching, whereas iron can be recovered via direct reduction using coke or other reductants [8,91,92]. Table 3 shows a summary of possible process routes used in previous research for possible metals present in CS.

Table 3. Possible recovery routes used in previous research on copper slag.

\begin{tabular}{ccc}
\hline Element & Recovery Route & Reference \\
\hline $\mathrm{Cu}, \mathrm{Ni}$ & Flotation, leaching & {$[9,14,34,93]$} \\
$\mathrm{Fe}$ & Reduction, magnetic separation & {$[12,24,94]$} \\
$\mathrm{Co}$ & Reduction & {$[29,34,61,95]$} \\
\hline
\end{tabular}

Africa is a continent blessed with abundant mineral deposits, which play an important role in its economic growth. Specifically, the mining and mineral processing sector accounts for a substantial share of the gross domestic product (GDP) around southern African, covered mostly by the sub-Saharan region. Due to the demand for viable minerals, the over-processing of mineral ores has subsequently led to severe environmental problems. 
Countries such as Botswana, Zambia, and South Africa have been significantly bolstered by their mining industry ( $10 \%$ contribution according to the SADC mining report of 1998). Mining in Botswana contributed around $40 \%$ of the GDP, along with $80 \%$ toward foreign exchange earnings. This led to the production of slag, which was usually disposed of on vacant land, thus posing a health risk to the environment and people in the area $[28,83]$. Botswana has been a major contributor of copper and nickel, surpassed only by South Africa and Zambia in 1996 [96-100].

\section{Conclusions}

Across the globe, slag is generated annually as a byproduct in enormous volumes of more than $400 \mathrm{Mt}$; hence, there is a need to fully appreciate the possible environmental impacts of this compound and its potential role as an economic material. This article reviewed various publications about slag, mostly CS slag, with respect to its environmental and socioeconomic impact. Despite its perception as a waste product, copper slag has the potential to be viable. Due to its environmental risks, the purpose of this article was to find viable avenues to minimize those risks by either reusing or recycling copper slag. In Botswana, it can be observed that the copper slag is dumped on vacant land next to mining operations, which can be used for other productive projects such as farming. Following exposure to rainfall and harsh weather conditions over decades, metal elements in the slag can seep into the ground, thereby affecting both the water table and the soil structure and leading to long-term environmental impacts if not attended to. With respect to the socioeconomic impact of slag, iron, cobalt, and nickel present in Botswana copper slag found at BCL can be recovered using pyro- and hydrometallurgical processes. These metals are highly sought after due to their properties; this would inject money into Botswana, create jobs, and bring life to the Selibe Phikwe mining town. This reclamation can, in turn, help improve the environmental impact of copper slag by rejuvenating the environment. Possible routes for recovery include leaching, direct reduction, and flotation of the slag.

Author Contributions: T.S.G.: Conceived and constructed the review paper. Reviewed critical information required for writing the manuscript. Wrote the paper. G.D. (Gwiranai Danha): Conceived and helped with prime objectives and relevance of the paper. Contributed to correcting the paper and guidance. T.A.M.: Conceived and helped in writing the paper about the socio-economic section. T.M.: Analyzed the paper and wrote paper. G.D. (Godfrey Dzinomwa): Analyzed paper and contributed to writing of paper. All authors have read and agreed to the published version of the manuscript.

Funding: This research received no external funding.

Data Availability Statement: The data that has been used is confidential.

Conflicts of Interest: The authors declare no conflict of interest.

\section{References}

1. Khanzadi, M.; Behnood, A. Mechanical properties of high-strength concrete incorporating copper slag as coarse aggregate. Constr. Build. Mater. 2009, 23, 2183-2188. [CrossRef]

2. Ilyas, S.; Lee, J.; Shin, D.; Kim, B. Bio-Hydrometallurgical Processing of Non-Ferrous Metals from Copper Smelting Slag; Trans Tech Publications Ltd.: Tokyo, Japan, 2013; Volume 825, pp. 250-253.

3. You, J.; Solongo S, K.; Gomez-Flores, A.; Choi, S.; Zhao, H.; Urik, M.; Ilyas, S.; Kim, H. Bioresource Technology Intensi fi ed bioleaching of chalcopyrite concentrate using adapted mesophilic culture in continuous stirred tank reactors. Bioresour. Technol. 2020, 307, 12318. [CrossRef] [PubMed]

4. Sarfo, P.; Das, A.; Wyss, G.; Young, C. Recovery of metal values from copper slag and reuse of residual secondary slag. Waste Manag. 2017, 70, 272-281. [CrossRef] [PubMed]

5. Shen, H.; Forssberg, E. An overview of recovery of metals from slags. Waste Manag. 2003, 23, 933-949. [CrossRef]

6. Madheswaran, C.K.; Ambily, P.S.; Dattatreya, J.K.; Rajamane, N.P. Studies on use of Copper Slag as Replacement Material for River Sand in Building Constructions. J. Inst. Eng. 2014, 95, 169-177. [CrossRef]

7. Edraki, M.; Baumgartl, T.; Manlapig, E.; Bradshaw, D.; Franks, D.M.; Moran, C.J. Designing mine tailings for better environmental, social and economic outcomes: A review of alternative approaches. J. Clean. Prod. 2014, 84, 411-420. [CrossRef]

8. Wang, X.; Geysen, D.; van Gerven, T.; Blanpain, B. Characterization of copper slag. In REWAS 2013; Springer: Cham, Switzerland, 2013; pp. 54-68. 
9. Gonzalez, C.; Parra, R.; Klenovcanova, A.; Imris, I.; Sánchez, M. Reduction of Chilean copper slags: A case of waste management project. Scand. J. Met. 2005, 34, 143-149. [CrossRef]

10. Urosevic, D.M.; Dimitrijevic, M.D.; Jankovic, Z.D. Recovery of Copper from Copper Slag and Copper Slag Flotation Tailings by Oxidative Leaching. Physicochem. Probl. Miner. Process. 2015, 51, 73-82.

11. Tripathi, N.; Peek, E.; Stroud, M. Advanced process modeling at the BCL smelter: Improving economic and en-vironmental performance. JOM 2011, 63, 63-67. [CrossRef]

12. Mikesell, R.F. The Selebi-Phikwe Nickel/Copper Mine in Botswana Lessons from a Financial Disaster; Blackwell Publishing Ltd.: Oxford, UK, 1984; Volume 8, pp. 279-290.

13. Yin, F.; Xing, P.; Li, Q.; Wang, C.; Wang, Z. Hydrometallurgy Magnetic separation-sulphuric acid leaching of Cu-Co-Fe matte obtained from copper converter slag for recovering $\mathrm{Cu}$ and Co. Hydrometallurgy 2014, 149, 189-194. [CrossRef]

14. Zhang, L.; Chen, H.; Deng, R.; Zuo, W.; Guo, B.; Ku, J. Growth behavior of iron grains during deep reduction of copper slag. Powder Technol. 2020, 367, 157-162. [CrossRef]

15. Li, H.; Zhang, W.; Wang, J.; Yang, Z.; Li, L.; Shih, K. Copper slag as a catalyst for mercury oxidation in coal combustion flue gas. Waste Manag. 2018, 74, 253-259. [CrossRef]

16. Cui, J.; Zhang, L. Metallurgical recovery of metals from electronic waste: A review. J. Hazard. Mater. 2008, 158, 228-256. [CrossRef] [PubMed]

17. Sibanda, V.; Sipunga, E.; Danha, G.; Mamvura, T.A. Heliyon Enhancing the flotation recovery of copper minerals in smelter slags from Namibia prior to disposal. Heliyon 2020, 6, e03135. [CrossRef] [PubMed]

18. Mizerna, K. Mobility of heavy metals from metallurgical waste in the context of sustainable waste management. Econ. Environ. Stud. 2016, 16, 819-830.

19. Potysz, A.; Kierczak, J. Dissolution of lead matte and copper slag upon exposure to rhizosphere-like conditions. Geosci. Rec. 2017, 4, 21-32. [CrossRef]

20. Gabasiane, T.S.; Danha, G.; Bhero, S. Waste Management and Treatment of Copper Slag BCL, Selebi Phikwe Botswana: Waste Management and Treatment of Review Copper Slag BCL, Selebi Botswana: Review. Procedia Manuf. 2019, 35, 494-499. [CrossRef]

21. Wang, X.; Geysen, D.; Tinoco, S.V.P.; D’Hoker, N.; Van Gerven, T.; Blanpain, B. Characterisation of copper slag in view of metal recovery. Miner. Process. Extr. Met. 2015, 124, 83-87. [CrossRef]

22. Bulut, G. Recovery of copper and cobalt from ancient slag. Waste Manag. Res. 2006, 24, 118-124. [CrossRef]

23. Busolic, D.; Parada, F.; Parra, R.; Sanchez, M.; Palacios, J.; Hino, M. Recovery of iron from copper flash smelting slags. Miner. Process. Extr. Met. 2011, 120, 32-36. [CrossRef]

24. Gorai, B.; Jana, R. Premchand Characteristics and utilisation of copper slag-A review. Resour. Conserv. Recycl. 2003, 39, 299-313. [CrossRef]

25. Pérez, K.; Toro, N.; Gálvez, E.; Robles, P.; Wilson, R.; Navarra, A. Environmental, economic and technological factors affecting Chilean copper smelters-A critical review. J. Mater. Res. Technol. 2021, 15, 213-225. [CrossRef]

26. Santoro, S.; Estay, H.; Avci, A.H.; Pugliese, L.; Ruby-Figueroa, R.; Garcia, A.; Aquino, M.; Nasirov, S.; Straface, S.; Curcio, E. Membrane technology for a sustainable copper mining industry: The Chilean paradigm. Clean. Eng. Technol. 2021, 2, 100091. [CrossRef]

27. Sánchez, M.; Sudbury, M. Physicochemical Characterization of Copper Slag and Alter-Natives of Friendly Environmental Management. J. Min. Metall. Sect. B Metall. J. Min. Met. Sect. B Met. 2013, 49, 161-168. [CrossRef]

28. Asare, B.K.; Darkoh, M.B.K. Socio-Economic and Environmental Impacts of Mining in Botswana: A Case Study of the SelebiPhikwe Copper-Nickel Mine. East. Afr. Soc. Sci. Res. Rev. 2001, 17, 1-41.

29. Jones, R.T.; Denton, G.M.; Reynolds, Q.G.; Parker, J.A.L.; van Tonder, G.J.J. Recovery of cobalt from slag in a DC arc furnace at Chambishi, Zambia. J. S. Afr. Inst. Min. Metall. 2002, 102, 5-9.

30. Hwang, A. Mineral Industry Surveys. Cobalt in March. 2021. Available online: https://prd-wret.s3.us-west-2.amazonaws.com/ assets/palladium/production/atoms/files/mis-202103-cobal.pdf (accessed on 26 October 2021).

31. Dhir, R.K.; de Brito, J.; Mangabhai, R.; Lye, C.Q. Use of Copper Slag in Geotechnical Applications. Sustain. Constr. Mater. Copp. Slag 2017, 211-245. [CrossRef]

32. Piatak, N.M.; Parsons, M.; Seal, R.R. Characteristics and environmental aspects of slag: A review. Appl. Geochem. 2015, 57, 236-266. [CrossRef]

33. Mihajlovi, A.; Kora, M.; Gavrilovski, M.; Jovanovi, N. The Effect of Cooling Rate of Slag from Primary Copper Production in the Valorization of Copper. Met. Mater. Eng. 2015, 21, 127-141. [CrossRef]

34. Huaiwei, Z.; Xin, H. Resources, Conservation and Recycling An overview for the utilization of wastes from stainless steel industries. Resour. Conserv. Recycl. 2011, 55, 745-754. [CrossRef]

35. Guo, Z.; Zhu, D.; Pan, J.; Wu, T.; Zhang, F. Improving Beneficiation of Copper and Iron from Copper Slag by Modifying the Molten Copper Slag. Metals 2016, 6, 86. [CrossRef]

36. Malema, M.T.; Legg, A.C. Recent improvements at the BCL Smelter. In South African Pyrometallurgy; South African Institute of Mining and Metallurgy: Johannesburg, South Africa, 2006; pp. 5-8. Available online: https://www.911metallurgist.com/blog/ wp-content/uploads/2016/02/Recent-Improvements-at-the-BCL-Smelter.pdf (accessed on 1 November 2021).

37. Potysz, A. Copper Metallurgical Slags: Mineralogy, Bio/Weathering Processes and Metal Bioleaching. 2016. Available online: https:/ / tel.archives-ouvertes.fr/tel-01407256/file/TH2015PESC1201_diffusion.pdf (accessed on 1 November 2021). 
38. Wu, P.; Jiang, L.Y.; He, Z.; Song, Y. Treatment of metallurgical industry wastewater for organic contaminant removal in China: Status, challenges, and perspectives. Environ. Sci. Water Res. Technol. 2017, 3, 1015-1031. [CrossRef]

39. Echeverry-Vargas, L.; Rojas-Reyes, N.R.; Estupiñán, E. Characterization of copper smelter slag and recovery of residual metals from these residues. Rev. Fac. Ing. 2017, 26, 61-71. [CrossRef]

40. Mihailova, I.; Mehandjiev, D. Characterization of fayalite from copper slags. J. Univ. Chem. Technol. Metall. 2010, 45, 317-326.

41. Fan, Y.; Shibata, E.; Iizuka, A.; Nakamura, T. Crystallization Behaviors of Copper Smelter Slag Studied Using Time-TemperatureTransformation Diagram. Mater. Trans. 2014, 55, 958-963. [CrossRef]

42. Olubambi, P.A.; Ndlovu, S.; Potgieter, J.H.; Borode, J.O. Influence of applied mineralogy in developing an optimal hydrometallurgical processing route for complex sulphide ores. Miner. Process. Extr. Metall. Rev. 2006, 27, 143-158. [CrossRef]

43. Zander, M.; Friedrich, B. Improving Copper Recovery from Production Slags by Advanced Stirring Methods. Proc. EMC 2011, 2011, 1-17.

44. Belhadj, E.; Diliberto, C.; Lecomte, A. Cement \& Concrete Composites Characterization and activation of Basic Oxygen Furnace slag. Cem. Concr. Compos. 2012, 34, 34-40.

45. Zhang, H.; Hu, C.; Gao, W.; Lu, M. Recovery of iron from copper slag using coal-based direct reduction: Reduction characteristics and kinetics. Minerals 2020, 10, 973. [CrossRef]

46. Gabasiane, T.; Danha, G.; Mamvura, T.; Mashifana, T.; Dzinomwa, G. Characterization of copper slag for beneficiation of iron and copper. Heliyon 2021, 7, e06757. [CrossRef]

47. Yang, Z.; Lin, Q.; $\mathrm{Lu}, \mathrm{S}$; $\mathrm{He}$, Y.; Liao, G.; Ke, Y. Effect of $\mathrm{CaO} / \mathrm{SiO}_{2}$ ratio on the preparation and crystallization of glass-ceramics from copper slag. Ceram. Int. 2014, 40, 7297-7305. [CrossRef]

48. Piatak, N.M.; Ii, R.R.S.; Hoppe, D.A.; Green, C.J.; Buszka, P.M. Geochemical Characterization of Iron and Steel Slag and Its Potential to Remove Phosphate and Neutralize Acid. Minerals 2019, 9, 468. [CrossRef]

49. Tsymbulov, L.; Kongoli, F.; McBow, I.; Pigarev, S. Composition and characteristics of slags from continuous con-verting of copper matte and concentrate. Trans. Inst. Min. Metall. Sect. C Miner. Process. Extr. Metall. 2014, 123, 10-20. [CrossRef]

50. Cardona, N.; Coursol, P.; Vargas, J.; Parra, R. The physical chemistry of copper smelting slags and copper losses at the paipote SmelterPart 2-characterisation of industrial slags. Can. Metall. Q. 2011, 50, 330-340. [CrossRef]

51. Manasse, A.; Mellini, M. Chemical and textural characterisation of medieval slags from the Massa Marittima smelting sites (Tuscany, Italy). J. Cult. Herit. 2002, 3, 187-198. [CrossRef]

52. Parada, F.; Parra, R.; Marquez, F.; Jara, R.; Carrasco, J.C.; Palacios, J. Management of Copper Pyrometallurgical Slags: Giving Additional Value to Copper Mining Industry; The South African Institute of Mining and Metallurgy: Johannesburg, South Africa, 2004; pp. 543-550. Available online: http:/ / www.saimm.co.za/Conferences/MoltenSlags2004/543-Sanchez.pdf (accessed on 1 November 2021).

53. Dong, C.; Liu, X.; Qin, W.; Lu, Q.; Wang, X.; Shi, S.; Yang, Y. Deep reduction behavior of iron oxide and its effect on direct CO oxidation. Appl. Surf. Sci. 2012, 258, 2562-2569. [CrossRef]

54. Biswas, S.; Satapathy, A. Use of copper slag in glass-epoxy composites for improved wear resistance. Waste Manag. Res. 2010, 28, 615-625. [CrossRef]

55. Peng, Z.; Gregurek, D.; Wenzl, C.; White, J.F. Slag Metallurgy and Metallurgical Waste Recycling. JOM 2016, 68, 2313-2315. [CrossRef]

56. Li, Y.; Perederiy, I.; Papangelakis, V.G. Cleaning of waste smelter slags and recovery of valuable metals by pres-sure oxidative leaching. J. Hazard. Mater. 2008, 152, 607-615. [CrossRef]

57. Li, S.; Pan, J.; Zhu, D.; Guo, Z.; Xu, J.; Chou, J. A novel process to upgrade the copper slag by direct reduction-magnetic separation with the addition of Na 2 CO 3 and CaO. Powder Technol. 2019, 347, 159-169. [CrossRef]

58. Chen, X.; Mao, J.; Tian, H. Analysis of China's Iron Trade Flow: Quantity, Value and Regional Pattern. Sustainability 2020, 12, 10427. [CrossRef]

59. Jiang, H.D.; Hao, W.T.; Xu, Q.Y.; Liang, Q.M. Socio-economic and environmental impacts of the iron ore re-source tax reform in China: A CGE-based analysis. Resour. Policy 2020, 68, 101775. [CrossRef]

60. Wårell, L. An analysis of iron ore prices during the latest commodity boom. Miner. Econ. 2018, 31, 203-216. [CrossRef]

61. Nadirov, R.; Syzdykova, L.; Zhussupova, A. Copper smelter slag treatment by ammonia solution: Leaching process optimization. J. Cent. South Univ. 2017, 24, 2799-2804. [CrossRef]

62. Bobicki, E.R.; Liu, Q.; Xu, Z. Microwave Treatment of Ultramafic Nickel Ores: Heating Behavior, Mineralogy, and Comminution Effects. Minerals 2018, 8, 524. [CrossRef]

63. Legg, A.C.; Ntsipe, L.; Bogopa, M.; Dzinomwa, G. Modernisation of the BCL Smelter. J. S. Afr. Inst. Min. Metall. 2009, 109, 53-68. Available online: http:/ /www.saimm.co.za/Journal/v109n11p671.pdf (accessed on 1 November 2021).

64. Li, K.; Ping, S.; Wang, H.; Ni, W. Recovery of iron from copper slag by deep reduction and magnetic beneficiation. Int. J. Miner. Metall. Mater. 2013, 20, 1035-1041. [CrossRef]

65. Wang, H.-Y.; Song, S.-X. Separation of silicon and iron in copper slag by carbothermic reduction-alkaline leaching process. J. Cent. South Univ. 2020, 27, 2249-2258. [CrossRef]

66. Cheng, X.-L.; Zhao, K.; Qi, Y.-H.; Shi, X.-F.; Zhen, C.-L. Direct Reduction Experiment on Iron-Bearing Waste Slag. J. Iron Steel Res. Int. 2013, 20, 24-29. [CrossRef] 
67. Thomas, J.; Thaickavila, N.N.; Abrahamb, M.P. Copper or ferrous slag as substitutes for fine aggregates in con-crete. Adv. Concr. Constr. 2018, 6, 545-560.

68. Erdenebold, U.; Choi, D.H.; Ho, K.S.; Cheol, K.G.; Wang, J.P. A study on reduction of copper smelting slag by carbon for recycling into metal values and cement raw material. Sustainability 2020, 12, 1421. [CrossRef]

69. Guo, H.; Yin, S.; Yu, Q.; Yang, X.; Huang, H.; Yang, Y.; Gao, F. Resources, Conservation \& Recycling Iron recovery and active residue production from basic oxygen furnace (BOF) slag for supplementary cementitious materials. Resour. Conserv. Recycl. 2018, $129,209-218$.

70. Kubissa, W.; Jaskulski, R.; Gil, D.; Wilińska, I. Holistic Analysis of Waste Copper Slag Based Concrete by Means of EIPI Method. Buildings 2019, 10, 1. [CrossRef]

71. Muhlare, T.A.; Groot, D.R. Recovery of Copper from Reverberatory Copper Slag and Production of a Leach Residue used as a Portland Cement Additive. In Proceedings of the Copper Cobalt Africa, Incorporating the 8th Southern African Base Metals Conference, AVANI Victoria Falls Hotel, Livingstone, Zambia, 9-13 July 2018.

72. Deveci, H.; Süngün, H. Utilization of flotation wastes of copper slag as raw material in cement production. J. Hazard. Mater. 2008, 159, 390-395.

73. Dey, A.; Dev, D.; Saha, P. Use of copper slag as sustainable aggregate. J. Mater. Cycles Waste Manag. 2015, 17, 13-26.

74. Kua, H.W. The consequences of substituting sand with used copper slag in construction: An embodied energy and global warming potential analysis using life cycle approach and different allocation methods kua life cycle assessment of copper slag. $J$. Ind. Ecol. 2013, 17, 869-879. [CrossRef]

75. Chew, S.H.; Bharati, S.K. Use of Recycled Copper Slag in Cement-Treated Singapore Marine Clay. In Advances in Environmental Geotechnics; Springer: Berlin/Heidelberg, Germany, 2010; pp. 705-710. Available online: http://link.springer.com/chapter/10.1 007/978-3-642-04460-1_83 (accessed on 23 October 2021).

76. Behnood, A. High-Strength Concrete Incorporating Copper Slag and Ground Pumice. March 2014. Available online: https: / / opus.lib.uts.edu.au/bitstream/10453/36942/1/01front.pdf (accessed on 1 November 2021).

77. Sreenivasulu, C.; Jawahar, J.G.; Sashidhar, C. Effect of Copper Slag on Micro, Macro, and Flexural Charac-teristics of Geopolymer Concrete. J. Mater. Civ. Eng. 2020, 32, 04020086. [CrossRef]

78. Edwin, R.S.; de Schepper, M.; Gruyaert, E.; de Belie, N. Effect of Copper Slag as Supplementary Cementitious Material (Scm) in Ultra High Performance Mortar (Uhpm). In Proceedings of the International Conference on Sustainable Structural Concrete (ICSSC 2015), La Plata, Argentina, 15-18 September 2015; pp. 15-18.

79. Das, S.; Gwon, H.S.; Khan, M.I.; Jeong, S.T.; Kim, P.J. Steel slag amendment impacts on soil microbial communities and activities of rice (Oryza sativa L.). Sci. Rep. 2020, 10, 6746. [CrossRef]

80. Schoenberger, E. Environmentally sustainable mining: The case of tailings storage facilities. Resour. Policy 2016, 49, 119-128 [CrossRef]

81. Franks, D.; Boger, D.V.; Côte, C.M.; Mulligan, D.R. Sustainable development principles for the disposal of mining and mineral processing wastes. Resour. Policy 2011, 36, 114-122. [CrossRef]

82. OECD. Local Content Policies in Minerals-Exporting Countries: The Case of Ghana Economic Context. December 2017. Available online: https: / / www.oecd.org/officialdocuments / publicdisplaydocumentpdf/?cote=TAD/TC/WP(2016)3/PART1/FINAL\& docLanguage $=$ En (accessed on 1 November 2021).

83. Mahar, A.; Wang, P.; Ali, A.; Awasthi, M.K.; Lahori, A.H.; Wang, Q.; Li, R.; Zhang, Z. Ecotoxicology and Environmental Safety Challenges and opportunities in the phytoremediation of heavy metals contaminated soils: A review. Ecotoxicol. Environ. Saf. 2016, 126, 111-121. [CrossRef]

84. Khalid, S.; Shahid, M.; Niazi, N.K.; Murtaza, B.; Bibi, I.; Dumat, C. A comparison of technologies for remediation of heavy metal contaminated soils. J. Geochem. Explor. 2017, 182, 247-268. [CrossRef]

85. Jones, R.T. Economic and environmentally beneficial treatment of slags in DC arc furnaces. In Proceedings of the Molten Slags, Fluxes an Salts Conference, Cape Town, South Africa, 25-28 January 2004; pp. 363-376.

86. Ekosse, G.; Van den Heever, D.J.; de Jager, L.; Totolo, O. Mineralogy of Tailings Dump around Selebi Phikwe Nickel-Copper Plant, Botswana. Miner. Eng. 2004, 8, 37-44. [CrossRef]

87. Ekkabaram, R. Enhancing the Clay Soil Characteristics Using Copper Slag Stabilization. December 2016, Volume 12, pp. 1-6. Available online: https:/ / core.ac.uk/download/pdf/322469938.pdf (accessed on 1 November 2021).

88. Ahmed, A.M.; Lyautey, E.; Bonnineau, C.; Dabrin, A.; Pesce, S. Environmental Concentrations of Copper, Alone or in Mixture with Arsenic, Can Impact River Sediment Microbial Community Structure and Functions. Front. Microbiol. 2018, 9, 1852. [CrossRef]

89. Bulut, G.; Perek, K.T.; Gül, A.; Arslan, F.; Önal, G. Recovery of metal values from copper slags by flotation and roasting with pyrite. Miner. Metall. Process. 2007, 24, 13-18. [CrossRef]

90. Markovic, Z.; Stirbanovic, Z.; Milanovic, D.; Urosevic, D.; Kongoli, F. Microscopy Analysis of Copper Slag and Its Processing by Flotation. In Proceedings of the 2014-Sustainable Industrial Processing Summit, Paphos, Cyprus; 29 June - 04 July 2014 ; pp. 231-236.

91. Guo, Z.; Pan, J.; Zhu, D.; Congcong, Y. Mechanism of composite additive in promoting reduction of copper slag to produce direct reduction iron for weathering resistant steel. Powder Technol. 2018, 329, 55-64. [CrossRef]

92. Guo, Z.; Zhu, D.; Pan, J.; Zhang, F.; Yang, C. Industrial Tests to Modify Molten Copper Slag for Improvement of Copper Recovery. JOM 2017, 70, 533-538. [CrossRef] 
93. Steinacker, S.R.; Antrekowitsch, J. Treatment of Residues from the Copper Industry with an Alternative Approach for Electric Furnace Slag. BHM Berg- Hüttenmännische Mon. 2017, 162, 252-257. [CrossRef]

94. Yuksel, U.; Tegin, I.; Ziyadanogullari, R. Recovery of Copper and Cobalt from Copper Slags as Selective. J. Environ. Sci. Eng. A 2017, 6, 388-394. [CrossRef]

95. Geng, C.; Wang, H.-J.; Hu, W.-T.; Li, L.; Shi, C.-S.; Ceng, C. Recovery of iron and copper from copper tailings by coal-based direct reduction and magnetic separation. J. Iron Steel Res. Int. 2017, 24, 991-997. [CrossRef]

96. Tanaka, H. Resources trend and use of directly reduced iron in steelmaking process. R D Res. Dev. Kobe Steel Eng. Rep. 2014, 64, 2-7. Available online: https://www.kobelco.co.jp/english/ktr/pdf/ktr_33/001-007.pdf (accessed on 1 November 2021).

97. Sen, R.; Dehiya, S.; Pandel, U.; Banerjee, M. Utilization of Low Grade Coal for Direct Reduction of Mill Scale to Obtain Sponge Iron: Effect of Reduction Time and Particle Size. Procedia Earth Planet. Sci. 2015, 11, 8-14. [CrossRef]

98. Battle, T.; Srivastava, U.; Kopfle, J.; Hunter, R.; McClelland, J. The Direct Reduction of Iron, 1st ed.; Elsevier Ltd.: Amsterdam, The Netherlands, 2014; Volume 3.

99. Arslan, C.; Arslan, F. Recovery of copper, cobalt, and zinc from copper smelter and converter slags. Hydrometallurgy 2002, 67, 1-7. [CrossRef]

100. Piatak, N.M.; Parsons, M.B.; Seal, R.R. Applied Geochemistry Characteristics and Environmental Aspects of Slag: A Review; Elsevier Ltd.: Amsterdam, The Netherlands, 2015; Volume 57. 